\title{
Short communication: \\ First record of Arapaima gigas (Schinz, 1822) (Teleostei: Osteoglossomorpha), in the Brantas River, Sidoarjo, East Java, Indonesia
}

\author{
MOHAMAD FADJAR ${ }^{1}$, R. ADHARYAN ISLAMY ${ }^{1, \boldsymbol{v}}$, ENDANG YULI HERAWATI ${ }^{2}$ \\ ${ }^{1}$ Departement of Aquaculture, Fisheries and Marine Science, Universitas Brawijaya. Jl. Veteran Malang No. 16, Malang City 65145, East Java, \\ Indonesia. Tel.: +62-341-553512. Fax.: +62-341-556837, `email: r.adhariyan@ gmail.com \\ ${ }^{2}$ Departemen of Water Resources Management, Fisheries and Marine Science, Universitas Brawijaya. Jl. Veteran Malang No. 16, Malang City 65145, \\ East Java, Indonesia
}

Manuscript received: 25 September 2019. Revision accepted: 13 November 2019.

\begin{abstract}
Fadjar M, Islamy RA, Herawati EY. 2019. Short communication: First record of Arapaima gigas (Schinz, 1822) (Teleostei: Osteoglossomorpha), in the Brantas River, Sidoarjo, East Java, Indonesia. Biodiversitas 20: 3527-3531. The arapaima (= Arapaima gigas) is the largest freshwater fish in the Neotropical region, obligate air-breathing fish that known to reach up to $3 \mathrm{~m}-3.90 \mathrm{~m}$ in length and $200 \mathrm{~kg}$ in weight endemic to the Amazon basin. Arapaima gigas is giant osteoglossomorph and obligate air-breathing fish and also a native species of the Amazon basin. We present the first record of Arapaima gigas (Schinz, 1822) in Brantas River, Sidoarjo, East Java, Indonesia with diagnostic meristic and morphometrics of the specimens analyzed following Stewart method. Herein, it recorded from the Brantas River basin. This record based on the finding of one live specimen on the tributary of Brantas River basin, and in situ observation of juveniles and adults in the river).
\end{abstract}

Keyword: Arapaimatidae, nonnative species, obligate air-breathing fish, pirarucu, predator fish

\section{INTRODUCTION}

Arapaima (Arapaima gigas (Schinz, 1822) is the largest freshwater fish in the Neotropical region, obligate airbreathing fish that known to reach up to $3 \mathrm{~m}-3.90 \mathrm{~m}$ in length and $200 \mathrm{~kg}$ in weight endemic to the Amazon Basin (Bard and Imbiriba 1986; Ferraris 2003; Ferreira 2013). Most Arapaima found in floodplain lakes during the dry season, and they emerge to surface to breathe every 5-15 min (Bard and Imbiriba 1986; Goulding et al. 1996; Queiroz and Sardinha 1999). Based on the holotype, Arapaima gigas distinguished from all other species by having total 30 of dentary teeth; 26 maxillary teeth; $2-2.5$ rows of teeth on the dentary; interorbital width $6.2 \% \mathrm{SL}$; orbit diameter $1.7 \% \mathrm{SL}$; parietals exposed, posterior margin of skull roof straight to moderately concave; separated caudal fin from the dorsal and anal fins by relatively short caudal peduncle; caudal-peduncle length divided by peduncle depth $0.06 \%$ SL; 17 total caudal-fin rays; dorsalmost lateral sensory cavity on preopercle broadly oval (Stewart 2013a, b).

Neotropical freshwater fish comprise the most diverse fish fauna of the world, with a significant contribution of small-sized species (Castro 1999). The giant osteoglossomorph and obligate air-breathing fish Arapaima gigas are a native species of the Amazon basin. Four valid species of Arapaima originally from Amazon watersheds, Brazil, and also found in other countries along the Amazon River, namely Columbia, Ecuador, Guyana and Peru
(Eschmeyer et al. 2018). Herein, this fish is non-native species in Indonesia, but we recorded it from the Brantas River basin. This record based on the finding of one live specimen on the tributary of Brantas River basin, and in situ observation of juveniles and adults in the river.

Arapaima is very dangerous for Indonesia's native river environment because it is a carnivorous/predatory fish whose food is other types of fish, crustaceans, frogs, birds found around the surface of the waters (Hadiaty 2017). It is essentially a fish predator. Some studies report that an arapaima consumes more than $8 \%$ of their biomass per day (i.e., $7 \mathrm{~kg}$ for a $90 \mathrm{~kg}$ fish) (Padilla et al. 2004). They reproduce at around $1.5 \mathrm{~m}$ in length and exhibits parental care (Queiroz 2000). Another study reports that the introduction of arapaima has caused severe environmental impacts such as causing a reduction of native fish populations, including many fish of high commercial value (Van 2006).

\section{MATERIALS AND METHODS}

Specimens of Arapaima gigas were captured using gill net on 02 July 2018. The specimen was treated with formalin for preservation and cataloged at the Ichthyology Laboratory, Brawijaya University, Malang, Indonesia (ARP/221/Icht.022/XI/2018). Diagnostic meristic and morphometrics of the specimens analyzed following Stewart (2013a, 2013b). 


\section{RESULTS AND DISCUSSION}

\section{New record}

On July 2, 2018, we visited the tributaries of the Brantas River (Figure 1), Sidoarjo District, East Java, Indonesia. The river is freshwater river with 0.5-4 meter deep in Sukodono Village, $7^{\circ} 23^{\prime} 42.3^{\prime \prime S} 112^{\circ} 40^{\prime} 32.7^{\prime \prime E}$ (DMS) (Figure 2), $7 \mathrm{~m}$ above sea level, we recorded the living adult Arapaima specimen. Arapaima gigas (Figure 3 ) then caught by fishermen using fishnet. The specimen was treated with formalin for preservation and cataloged at the Ichthyology Laboratory, Brawijaya University, Malang, Indonesia (ARP/221/Icht.022/XI/2018). Hereinafter, we explored the joined river and 8 July 2018 we found the other adult arapaima in Trosobo village, Sidoarjo District, East Java, $7^{\circ} 22^{\prime} 28^{\prime \prime S} 112^{\circ} 37^{\prime} 59^{\prime \prime E}$ (DMS), and in Cumpleng village, Sidoarjo District, East Java, 7²3'25.4"S $112^{\circ} 39^{\prime} 40.6^{\prime \prime} \mathrm{E}$ (DMS). Our total catch of arapaima was three adult fishes. However, we found no presence of Arapaima gigas juvenile.

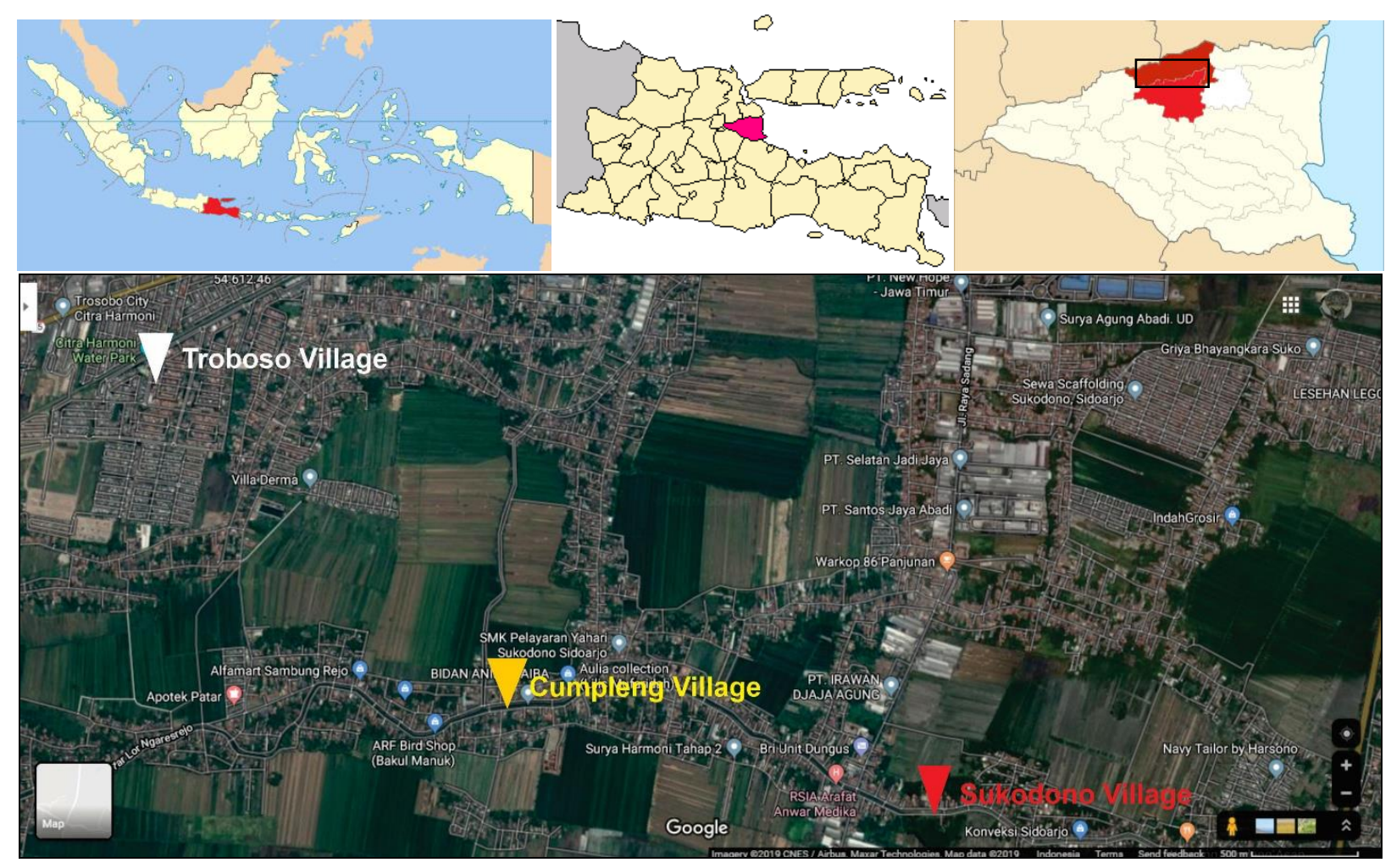

Figure 1. Records of Arapaima gigas in the tributaries of Brantas River, Sidoarjo, East Java, Indonesia

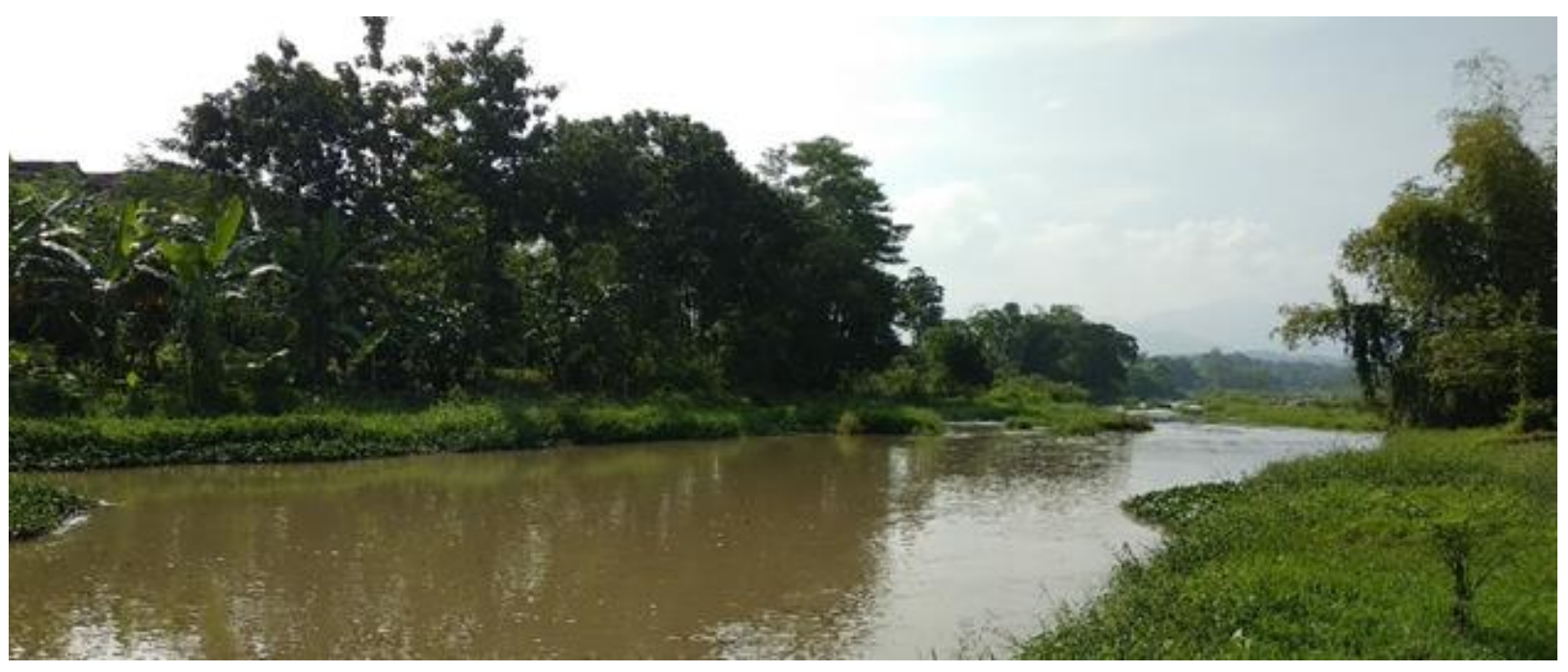

Figure 2. The left bank of Brantas River in Sukodono villages, where Arapaima gigas was recorded 


\section{Identification}

The specimen obtained by us is about $150 \mathrm{~cm}$ in total length (TL) and about $122 \mathrm{~cm}$ in standard length (SL), 32 of dentary teeth, 28 of maxillary teeth, 32 of premaxillary teeth; 3\% SL of orbit diameter, 5.6\% SL of inter-orbital width; parietals exposed, posterior margin of skull roof straight to moderately concave; separated fin of this fish from dorsal and anal fins by relatively short caudal peduncle; 11 of pectoral-fins rays I; 19 of branched caudalfin rays; pre-caudal vertebrae 41; caudal vertebrae 42; total vertebrae 83 , including ural centra and first centrum closely associated with basioccipital; dorsal-most lateral sensory cavity on preopercle broadly oval. We were not able to obtain caudal peduncle measurements due to the poor condition of the specimen (Fig. 3?). The set of available characters fits the diagnosis of Arapaima gigas, according to Stewart (2013a, 2013b). The discovery of the second and third arapaima was not possible for us to identify because it was taken over by the East Java Natural Resources Conservation Center.

\section{Discussion}

Arapaima gigas typically inhabits the Amazon River basin of South America and mainly found in Peru, Brazil, Colombia, Bolivia, and Guyana. They found in several different characteristics of habitat, such as the large tributaries of the Amazon River, the floodplain lakes, including the Rio Madeira and the Rio Machado in Brazil. Arapaima gigas inhabits both white water and clear water, much of which is also oxygen-deficient as it is located in rainforest swampland (Reis et al. 2003; Rojas 2004; Franco 2005; Castello 2008). Some studies report that arapaima has also been introduced into Bolivia, China, Cuba, Mexico, Philippines, Singapore, Thailand, as aquaculture animals (Goulding et al. 1996), and Parnaíba River basin, Northeastern Brazil (2014). Other confirmation, Arapaima records outside their original geographic distribution are from the upper Parnaíba River (Ramos et al. 2014) and the upper Madeira River (Ferreira 2013). There is no assessment evaluating the consequences of Arapaima's introduction to the native fauna. Nevertheless, some studies started an investigation on the possible environmental parameter to assess the profit and risk of Arapaima introducing. However, the Indonesian government still prohibits the entry of arapaima fish into Indonesian waters, and violators will be punished following article 16 of Law Number 45 of 2009 concerning Fisheries.

Besides, Arapaima gigas is also a type of predatory fish that can eat almost all animals that can be swallowed, especially small-sized fish and other animals that are on the surface of the water. Arapaima gigas, including fish, are competitors, which means they compete with other types of fish to get food, primarily preying on smaller fish. It is a predator that mainly prey on other fish. If a bird or another animal happens to be present, this big predator will also prey on that animal. The pirarucu usually finds food near the top of the water because it is an obligate air breather that needs to surface every 10-20 min (Lowe-McConnell 1987; Goulding 1980).

Arapaima is a fish that intentionally introduced into other habitats for cultivation as well as ornamental fish. However, there have been no definite reports of how arapaima fish can enter the Brantas River. We speculate that pirarucu was released into Brantas River by native people for an unclear purpose. In Indonesia, Arapaima gigas included in invasive fish, according to Indonesian Minister of Environment and Forestry Regulation Number 94, 2016, concerning Invasive Types.

Non-native species may have neutral or even beneficial effects on native biota and ecosystems (Cope and Winterbourn 2004; Johnson et al. 2009); others become invasive and establish spreading populations that negatively impact the recipient environment and its biota (Mack et al. 2000). The entry of non-native fish into local waters can increase the potential threat of extinction in small fish compared to local predator fish in terms of maximum feeding rate (Faria et al. 2019). Additive nonnative species will also effect synergizing of ecosystem, a network of beneficial direct and indirect interactions of community, leads to a population burst of current species where high abundance of the non-native species will reduce local populations even extirpating the native population (Braga et al. 2017). Another negative impact, such as biotic homogenization from non-native species which are possible to dominating in waters, synergistic disturbances in altered environments such as reservoirs, and cause negative ecological impacts on populations of native species in River tributaries (Padial et al. 2016).

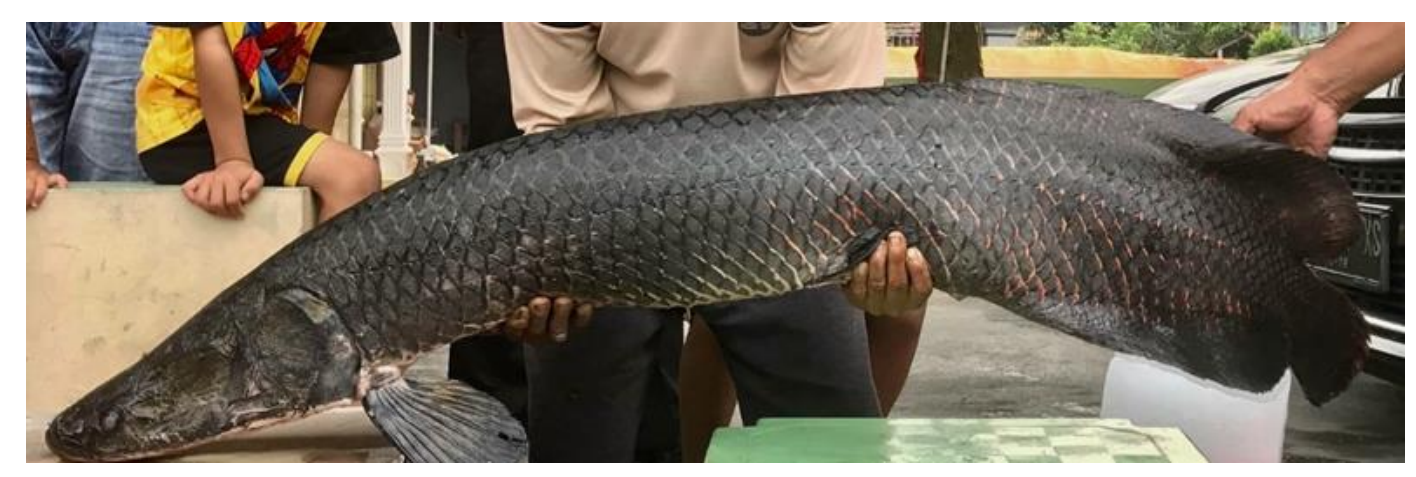

Figure 3. Arapaima gigas fresh specimen, not cataloged and not measured, from Brantas River, Sukodono Village, Sidoarjo District, East Java (ARP/221/Icht.022/XI/2018) 
Generally, activity of aquaculture considered to be the main factor for the non-native freshwater fish introduction from native to other zoogeographical regions (Valduga et al. 2016). The ornamental fish trade is also an important source of the direct release of unwanted organisms, i.e., fish that had been kept as pets, or via escapes from ornamental fish farming (Padilla and Williams 2004; Abilhoa et al. 2013). We assume that the ornamental trade is factor for the non-native fish such as arapaima, release to Brantas River. In general, biological invasions are complex processes that involve several phases (Garcia-Berthou 2007), which in this case can be interpreted as transporting the organism to a new region, introduction of arapaima into the wetlands, establishment, and dispersal, and integration or impact (Miranda-Chumacero 2012).

Non-native fish species are considered a critical threat to freshwater ecosystems. The potential for negative ecosystem impacts of the Arapaima gigas invasion as Nonnative fish species in Brantas river seems likely, considering the large body size, life history, and feeding ecology of this species, but has not yet been demonstrated (Van et al. 2015). We assume if the appearance of arapaima in the Brantas River will harm many sectors. Economically it will have a negative impact, such as reducing the stock of fisherman catches in the river and can eliminate fish resources needed by the community. Notwithstanding, to our knowledge, there is no assessment evaluating the consequences of Arapaima gigas introduction on the native fauna of Brantas River. Evaluations and investigation on the ecology, biology, abundance, and possible dispersal of the "pirarucu" routes in Brantas River is needed to evaluate the consequences of such appearance in the river.

Regulations on the prohibition of the entry of Arapaima gigas fish into the Indonesian marine environment have been established by the Minister of Maritime Affairs and Fisheries in 2014. It should be immediately socialized to the public, traders, and ornamental fish farmers then immediately enforced, subject to a penalty for these violators. If Arapaima gigas is found in public waters, it is immediately caught, taken out of Indonesian waters, then the meat can be shared with local society because even in their home country, this fish used for consumption.

\section{REFERENCES}

Abilhoa V, Bornatowski H, Vitule JRS. 2013. Occurrence of the alien invasive loach Misgurnus anguillicaudatus in the Iguaçu River Basin in Southern Brazil: a note of concern. J Appl Ichthyol 29: 257-259.

Bard J, Imbiriba EP. 1986. Piscicultura do pirarucu Arapaima gigas. Embrapa-Centro de Pesquisa Agropecuaria do Tropico Umido, Belem, Brazil. [Portuguese]

Braga RR, Gómez-Aparicio L, Heger T, Vitule JRS, Jeschke JM. 2017. Structuring evidence for invasional meltdown: broad support but with biases and gaps. Biol Invasions 20: 923-936.

Carvalho FR, Casatti L, Manzotti AR, Ravazzi DCW. 2015. First record of Arapaima gigas (Schinz, 1822) (Teleostei: Osteoglossomorpha), the "pirarucu", in the upper Paraná River Basin, Southeast Brazil. Check List 11: 1-4.

Castello L. 2008. Lateral migration of Arapaima gigas in floodplains of the Amazon. Ecol Freshw Fish 17: 38-46.

Castro RMC. 1999. Evolução da ictiofauna de riachos sulamericanos: padrões gerais e possíveis processos causais. in: Caramaschi EP,
Mazzoni R, Peres-Neto PR (eds) Ecologia de peixes de riachos: estado atual e perspectivas. Série Oecologia Brasiliensis, PPGEUFRJ, Rio de Janeiro, Brazil. [Portuguese]

Cope NJ, Winterbourn MJ. 2004. Competitive interactions between two successful molluscan invaders of fresh waters: an experimental study. Aquat Ecol 38: 83-91.

Eschmeyer WN, Fricke R, Van der Laan Y. 2018. Catalog of Fishes: Genera, species, references. http://www.calacademy.org/scientists/catalog-of-fishes-classification/

Faria L, Alexander ME, Vitule JRS. 2019. Assessing the impacts of the introduced channel catfish Ictalurus punctatus using the comparative functional response approach. Fish Manag Ecol 00:1-8.

Ferraris CJJ. 2003. Family Arapaimatidae (bonytongues). In: Reis RE, Kullander SO, Ferraris CJJ (eds.). Checklist of the freshwater fishes of South and Central America. EDIPUCRS, Porto Alegre. [America]

Ferreira E. 2013. Arapaimatidae. in: Queiroz LJ, Torrente VLJ, Ohara WM, Pires TS, Zuanon J, Doria CRC (eds) Peixes do rio Madeira. Dialeto Latin American Documentary, Porto Velho, Brazil. [Portuguese]

Franco RH. 2005. Contribución al conocimiento de la reproducción del pirarucú Arapaima gigas (Cuvier, 1817) (Pisces: Arapamidae) en cautivero. Trabajo de grado Universidad de la Amazonía, Facultad de Ciencias Básicas. Programa de Biología con énfasis en biorrecursos Florencia, Caquetá, Colombia. [Spanish]

Garcia-Berthou E. 2007. The characteristics of invasive fishes: What has been learned so far?. J Fish Biol 71: 33-55.

Goulding M. 1980. The Fishes and the Forest. Berkeley, CL.

Goulding M, Smith NJH, Mahar DJ. 1996. Floods of fortune: ecology and economy along the Amazon. Columbia University Press, New York.

Hadiaty RK. 2017. Arapaima gigas (schinz, 1822), Ikan air tawar terbesar di dunia, exotis namun sangat berbahaya bagi ikan asli Indonesia. Warta Iktiologi 2: 20-26. [Indonesian]

Johnson BM, Arlinghaus R, Martinez PJ. 2009. Are we doing all we can to stem the tide of illegal fish stocking?. Fisheries 34: 389-394.

Lowe MR 1987. Ecological Studies in Tropical Fish Communities. Cambridge University Press, London.

Mack RN, Simberloff D, Lonsdale WM, Evans H, Clout M, Bazzaz F. 2000. Biotic invasions: Causes, epidemiology, global consequences and control. Ecol Appl 3: 689-710.

Miranda-Chumacero G, Wallace R, Calderón H, Calderón G, Willink P, Guerrero M, Siles TM, Lara K, Chuqui D. 2012. Distribution of Arapaima (Arapaima gigas) (Pisces: Arapaimatidae) in Bolivia: implications in the control and management of a non-native population. BioInvasions Rec 1(2): 129-138.

Padial AA, Agostinho AA, Azevedo-Santos VM, Frehse FA, Lima-Junior DP, Magalhães ALB, Mormul RP, Pelicice FM, Bezerra LAV, Orsi ML, Petrere-Junior M, Vitule JRS. 2016. The 'tilapia law' encouraging non-native fish threatens Amazonian River Basins. Biodivers Conserv 26: 243-246.

Padilla DK, Williams SL. 2004. Beyond ballast water: aquarium and ornamental trades as sources of invasive species in aquatic ecosystems. Front Ecol Environ 2: 131-138.

Padilla P, Ismiño R, Alcántara F, Tello S. 2004. Efecto de la tasade alimentación en el crecimiento del paiche, Arapaima gigas. En: Bodmer R, Puertas P MEMORIA VI Congreso Internacional sobre Manejo de Fauna Silvestre en la Amazonia y Latinoamérica. 5 al 10 Septiembre 2004, Iquitos- Perú. [Spanish]

Queiroz HLD. 2000. Natural history and conservation of pirarucu, Àrapaima gigas, at the Amazonian Várzea: red giants in muddy waters. [Dissertation]. University of St Andrews, Scotland, UK.

Queiroz HL, Sardinha AD. 1999. A preservacão e o uso sustentado dos pirarucus em Mamirauá. In: Queiroz HL, Crampton WGR (eds) Estratégias para o manejo de recursos pesqueiros em Mamirauá. Sociedade Civil Mamirauá/Ministério de Ciência e Tecnologia /Conselho Nacional de Pesquisa, Mamirauá, Brazil. [Portuguese]

Ramos CA, Raulino JCN, da Menezes GC, do Carmo IB, Brasil EM, Affonso EG, Fernandes MN. 2014. Influences of Amazonian white and black waters on the hematological and biochemical plasma features of Arapaima gigas (Osteoglossiformes). J Life Sci 8 (3): 252261.

Reis RE, Kullander SO, Ferraris CJJ. 2003. Checklist of the freshwater fishes of South and Central America. EDIPUCRS, Porto Bello, Brazil.

Rojas G. 2004 Experiencias en el aprovechamiento de Arapaima gigas "paiche" en la cocha El Dorado, cuenca Yanayacu Pucate- 
Reserva Nacional Pacaya Samiria. Memorias del VI Congreso Internacional sobre Manejo de Fauna Silvestre en la Amazonía y Latinoamérica, 5-10 Septiembre 2004. [Spanish]

Stewart DJ. 2013a. Re-description of the Arapaima agassizi (Valenciennes), a rare fish from Brazil (Osteoglossomorpha: Osteoglossidae). Copeia 1: 38-51.

Stewart DJ. 2013b. A new species of Arapaima (Osteoglossomorpha: Osteoglossidae) from the Solimões River, Amazonas State, Brazil. Copeia 3: 470-476.

Valduga MO, Rafael DZ, Jean RV. 2016. Ecological impacts of nonnative tree species plantations are broad and heterogeneous: a Review of Brazilian Research. Anais Da Academia Brasileira De Ciências 88: 1675-1688.

Van DPA. 2006. Propuesta de estrategia y proyecto demanejo y desarrollo pesquero para el norte amazónico (Bolivia). Propuesta enviada a la FAO, Rome. [Spanish]

Van DPA, Claudia CM, Milton Z, Fernando MCV, Joachim C, Julian DO. 2015. The expansion of Arapaima cf. gigas (Osteoglossiformes: Arapaimidae) in the Bolivian Amazon as informed by citizen and formal science. Management of Biological Invasions 4: 375383.Ramos TPA, Ramos RTDC, Ramos SAQ. 2014. Ichthyofauna of the Parnaíba river Basin, Northeastern Brazil. Biota Neotrop 14: 1-8. 